\title{
SITE SUITABILITY ANALYSIS FOR DISSEMINATION OF SALT-TOLERANT RICE VARIETIES IN SOUTHERN BANGLADESH
}

\author{
D. D. Sinha*, A. N. Singh and U. S. Singh \\ International Rice Research Institute (IRRI) - India Office \\ NASC Complex, Pusa, New Delhi-110 012 \\ *Corresponding author: d.sinha@irri.org
}

KEY WORDS: IRRI, Salt-tolerant rice varieties, Rice suitability map, Remote Sensing \& GIS

\begin{abstract}
:
Bangladesh is a country of 14.4 million ha geographical area and has a population density of more than 1100 persons per sq. km. Rice is the staple food crop, growing on about $72 \%$ of the total cultivated land and continues to be the most important crop for food security of the country. A project "Sustainable Rice Seed Production and Delivery Systems for Southern Bangladesh" has been executed by the International Rice Research Institute (IRRI) in twenty southern districts of Bangladesh. These districts grow rice in about 2.9 million ha out of the country's total rice area of 11.3 million ha. The project aims at contributing to the Government of Bangladesh's efforts in improving national and household food security through enhanced and sustained productivity by using salinity-, submergence- and drought- tolerant and high yielding rice varieties. Out of the 20 project districts, 12 coastal districts are affected by the problem of soil salinity. The salt-affected area in Bangladesh has increased from about 0.83 million ha in 1973 to 1.02 million ha in 2000, and 1.05 million ha in 2009 due to the influence of cyclonic storms like 'Sidr', 'Laila' and others, leading to salt water intrusion in croplands.

Three salinity-tolerant rice varieties have recently been bred by IRRI and field tested and released by the Bangladesh Rice Research Institute (BRRI) and Bangladesh Institute of Nuclear Agriculture (BINA). These varieties are BRRI dhan- 47 and Bina dhan-8 and 10. However, they can tolerate soil salinity level up to EC 8-10 dSm${ }^{-1}$, whereas the EC of soils in several areas are much higher. Therefore, a large scale dissemination of these varieties can be done only when a site suitability analysis of the area is carried out. The present study was taken up with the objective of preparing the site suitability of the salt-tolerant varieties for the salinity-affected districts of southern Bangladesh. Soil salinity map prepared by Soil Resources Development Institute of Bangladesh shows five classes of salinity. viz., non-saline with some very slight saline soil, very slightly saline with some slight saline soil, slightly saline with some moderately saline soil, strongly saline with some moderately saline soil, and very strongly saline with some strongly saline soil. The soil EC level of different classes range from $2 \mathrm{dSm}^{-1}$ to $>16 \mathrm{dSm}^{-1}$. The soil map was geo-referenced and digitized using Arc GIS. Salinity tolerance characteristics of the rice varieties were matched with the soil characteristics shown on the map. Three suitability classes were made; soils suitable for salt-tolerant varieties, not suitable for salt-tolerant varieties due to high soil salinity, and suitable for other high yielding varieties due to slight salinity. The mauza (smallest revenue unit) boundary provided by the Bangladesh Agriculture Research Council was also geo-referenced and digitized in the same projection. Overlaying and intersecting the mauza boundary on the soil suitability map provided the suitable and not suitable mauzas. A total of 4070 mauzas in the 12 salinity-affected districts were listed and maps showing suitability of mauza prepared. About 0.6 million ha out of total 0.87 million ha salinity affected area were found suitable for growing the salinity-tolerant BRRI dhan-47, Bina dhan-8 and -10 in these districts. The maps and other generated information have helped the Dept. of Agriculture Extension (DAE) of Bangladesh in large scale dissemination of seeds of the salinity-tolerant rice varieties in different districts during the past two years.
\end{abstract}

\section{Introduction}

Bangladesh is a deltaic country with 14.4 million ha geographical area. About $80 \%$ of the country's area consists of alluvial sediments deposited by the rivers Ganga, Brahmaputra, Tista, Jamuna, Meghna and their tributaries (Haque, 2006). These alluvial areas having fertile soils are most suited for rice cultivation. Rice is grown in about 11.3 million ha and is the most important food crop of Bangladesh. However, a part of the cultivable area in coastal districts is affected with varying degree of soil salinity due to the ingress of saline water during high tides. Soil salinity is also believed to be responsible for low land use as well as cropping intensity in these districts (Rahman \& Ahsan, 2001).

The area affected by soil salinity in Bangladesh has been reported to be increasing due to the climate change effect. The salinity affected area increased from about 0.83 million ha in 1973 to 1.02 million ha in 2000, and 1.05 million ha in 2009 (SRDI, 2010). The increase in soil salinity area during 20002009 has been reported to be due to the influence of severe cyclonic storms like 'Sidr', 'Laila' and others, leading to salt water intrusion in croplands. Increasing salinity is also leading to decreased rice yields. Sarwar (2005) investigated the loss of rice production in a village of Satkhira district in southern Bangladesh and found that rice production in 2003 was 1,151 metric tons less than the year 1985, corresponding to a loss of 69 per cent. Out of this decreased production, 77 per cent was due to the conversion of rice field into shrimp pond, and 23 per cent because of the yield loss due to salinity increase.

Some of the IRRI-bred high yielding rice varieties equipped with salt-tolerances have been tested by the Bangladesh Rice Research Institute (BRRI) and Bangladesh Institute of Nuclear Agriculture (BINA) and released recently by the Government. These varieties are-BRRI dhan 47, Binadhan- 8 and -10 . These varieties have been tested in the coastal region of Bangladesh and have proved their high performance during Boro season (Khandker et al., 2014). However, these salt-tolerant varieties can grow in soil salinity level upto EC $8-10 \mathrm{dSm}^{-1}$, whereas the EC of soils in several coastal districts is much higher. Therefore, dissemination of these varieties can be done only when a site suitability analysis of the area is carried out.

The USAID supported a project on 'Sustainable Rice Seed Production and Delivery Systems for southern Bangladesh' with 
the aim of improving food security through enhanced and sustained productivity. The project activities included scaling up the production and distribution of quality seeds of high yielding and stress-tolerant rice varieties, and to make them available to the farmers on a site-specific basis in 20 districts of southern Bangladesh. The present study was, therefore, taken up with the objective of generating site suitability information for dissemination of salt-tolerant rice varieties in southern Bangladesh.

Since mauza (lowest administrative revenue unit) suitability level analysis for the dissemination of salt-tolerant rice varieties has not been done using remote sensing and GIS in the study districts, this research is important for the dissemination of BRRI dhan-47, Binadhan- 8 and -10 in suitable mauzas of the districts. Out of 20 project districts of southern Bangladesh, 12 districts are affected by the problem of soil salinity (Singh et al., 2012).

\section{Study area details}

The study area comprises of USAID-supported 20 project districts of southern

Bangladesh-

Bagerhat, Barguna,

Barisal, Bhola,

Chuadanga,

Faridpur,

Gopalganj,

Jhalokati, Jessore,

Jhenaidaha,

Khulna, Madaripur,

Magura, Meharpur,

Narail, Patuakhali,

Pirojpur, Rajbari,

Satkhira

and

Shariatpur.

Location of these districts is given in

Fig. 1. These districts grow rice in about 2.9 million ha out of the country's total rice area of 11.3 million ha. Rice in Bangladesh is grown

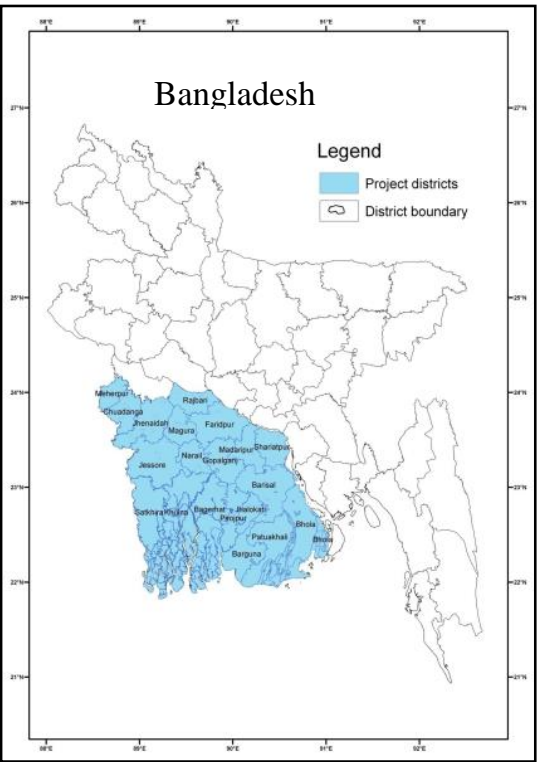

Fig.1. Location map of study area

in three seasons in a year. These are- Aus (April to August), Aman (July to November) and Boro (December to May). The district-wise rice area in different seasons is shown in Table 1. Out of the total rice area of 2.9 million ha, about $55 \%$ is grown in Aman, whereas only $14 \%$ in Aus, and $31 \%$ in Boro. In the districts of Barisal division, which is most affected by salinity, the extent of Boro is low, only $14 \%$ as compared to Khulna and Dhaka division, having $39 \%$ and $50 \%$ area, respectively, under Boro. This is because the crop in the salinity affected districts suffer most during the Boro or dry season as the salts come up on the surface when the soil dries up. In Barisal division, farmers instead grow rice in the Aus season (23\% of total rice), taking advantage of early monsoon rains starting in the month of April. The salinity affected areas are predominantly inhabitated by impoverished communities with fewer opportunities for food security and livelihood option.

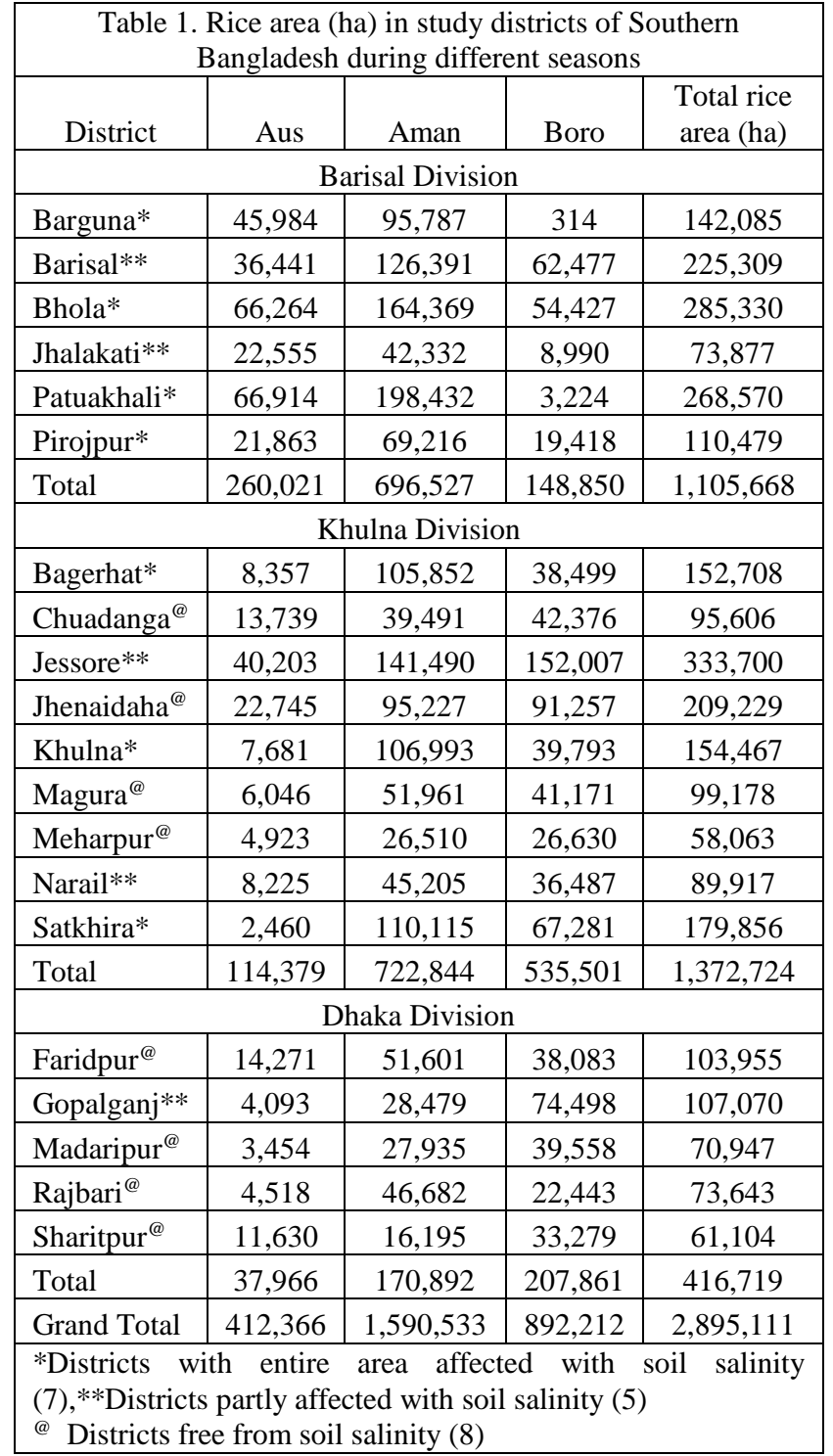

Soil salinity is restricted to 12 out of 20 study districts. These are: Barguna, Barisal, Bhola, Jhalakati, Patuakhali and Pirojpur districts in Barisal division; Bagerhat, Jessore, Khulna, Narail and Satkhira districts in Khulna division; and Gopalganj district in Dhaka division. These districts cover approx. 0.874 million ha salinity affected area. The extent of cultivated area and salinity affected area in study districts has been presented in Table 2. The Soil Resources Development Institute (SRDI) of Bangladesh has prepared a soil salinity map (Fig.2), and the salinity classes are shown in 5 units with the range of salinity given Table 3.

Salinity affects rice crop most during the Boro season as the salt concentration becomes high during the dry season. During the Aus and Aman seasons, the salinity gets diluted due to the monsoon rains and its effect on rice yield is not significant. There seems to be a good prospect for increasing the rice area and production in these salinity-affected districts by using the new salinity-tolerant BRRI dhan 47, Binadhan- 8 and -10 . Currently, BRRI dhan 28 and 29 and some local varieties are popular among the farmers in the Boro season. However, these varieties either fail or do not provide high yield during Boro due to their being sensitive to salinity. 


\begin{tabular}{|l|l|c|c|}
\hline \multicolumn{4}{|c|}{$\begin{array}{l}\text { Table 2. Extent (ha) of cultivated and salinity-affected area in } \\
\text { study districts }\end{array}$} \\
\hline Division & District & $\begin{array}{c}\text { Cultivated area } \\
\text { in salt-affected } \\
\text { Upazilas }\end{array}$ & Saline area \\
\hline Barisal & Barguna & 135,334 & 95,620 \\
\hline & Barisal & 71,081 & 12,360 \\
\hline & Bhola & 148,109 & 94,570 \\
\hline & Jhalakati & 24,946 & 4,620 \\
\hline & Patuakhali & 215,760 & 155,180 \\
\hline & Pirojpur & 85,282 & 35,830 \\
\hline Khulna & Bagerhat & 150,744 & 131,120 \\
\hline & Jessore & 53,249 & 14,990 \\
\hline & Khulna & 165,789 & 147,960 \\
\hline & Narail & 51,769 & 17,710 \\
\hline & Satkhira & 184,316 & 153,110 \\
\hline Dhaka & Gopalganj & 51,554 & 10,460 \\
\hline & Total & $1,337,933$ & 872330 \\
\hline
\end{tabular}

\begin{tabular}{|c|c|}
\hline Salinity class & $\mathrm{EC}\left(\mathrm{dSm}^{-1}\right)$ \\
\hline Non saline to very slight saline & $2-4$ \\
\hline Very slight saline to slight saline & $4-8$ \\
\hline Slight saline to moderate saline & $8-12$ \\
\hline Moderate saline to strong saline & $12-16$ \\
\hline Strong saline to very strong saline & $>16$ \\
\hline
\end{tabular}

\section{Characteristics of salt-tolerant rice varieties}

Characteristics of salt-tolerant rice varieties released recently in Bangladesh are as follows:

BRRI dhan 47: (IR 63307-4B-4-3) is a salt-tolerant, high yielding rice variety, released in 2007 for cultivation in Bangladesh during the Boro season. It is a semi dwarf $(105 \mathrm{~cm})$, long duration (148-152days) variety with a yield potential of 6 $\mathrm{t} / \mathrm{ha}$. The variety can tolerate salinity level of EC $12-14 \mathrm{dSm}^{-1}$ at seedling stage and 6-8 $\mathrm{dSm}^{-1}$ during the vegetative growth stages. The harvesting of rice is to be done at $80 \%$ grain maturity, due to shattering of grain, and careful harvesting and carrying to threshing floor is required.

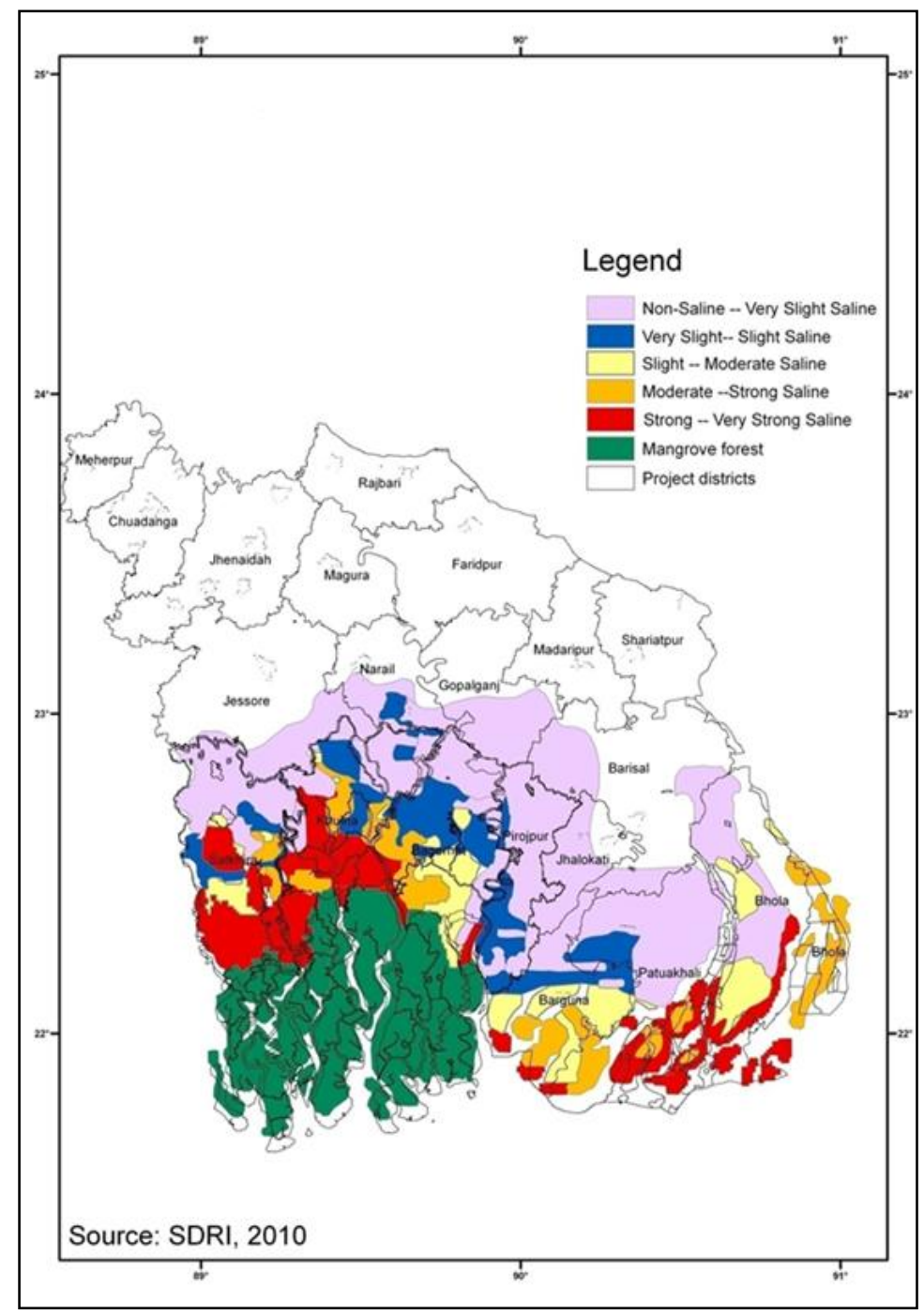

Fig. 2. Soil salinity map units in study districts of southern Bangladesh 
Binadhan-8: IR 66946-3R-149-1-1 is a salt tolerant high yielding rice variety, released by the Bangladesh Institute of Nuclear Agriculture (BINA) in 2010. It is a semi dwarf, early maturing and medium bold grain rice variety and requires 130135 days to mature. It is moderately resistant to bacterial leaf blight, sheath blight, brown plant hopper, stem borer and rice hispa. Under salt stress, maximum grain yield is $5.5 \mathrm{t} / \mathrm{ha}$ (average 4.5-5.5 t/ha) and in non-saline area, maximum 9.0 t/ha (average 7.5-8.5 t/ha). The variety is salt tolerant upto EC 10 $\mathrm{dSm}^{-1}$ and is suitable for both 'Boro' and 'Aman'.

Binadhan-10: It is a salt-tolerant, high yielding rice variety developed by BINA, and approved by the Technical Committee of National Seed Board for release. It is a medium duration variety (127-132 days maturity) and can tolerate salt stress of 10-12 $\mathrm{dS} \mathrm{m}^{-1}$. Farmers can get a yield of 5.5- 6.5 t/ha in saline and 7.5- $8.5 \mathrm{t} / \mathrm{ha}$ in non-saline lands. The plants have strong stem, and there is no lodging even in stormy weather. The variety can be cultivated in both Boro and Aman seasons.

\section{Criteria used in selection of area for dissemination of salt- tolerant rice varieties}

The criteria used in selection of area for dissemination of salttolerant varieties in Boro season are:

(i) The area should not have very high salinity (EC not more than $12 \mathrm{dSm}^{-1}$ ) as the available salt tolerant varieties can perform best at this salinity level.

(ii) Surface water for irrigation should be available. Groundwater quality, if being used for Boro, should be good.

(iii) Preferably select areas where some boro rice is being grown nearby (may be with low yield due to salt stress, yields need to be improved using salt tolerant varieties).

\section{Data used and Methodology}

The following data and maps were used for site suitability analysis:

(i) Soil salinity map from SRDI (2010)

(ii) Rice growing areas map from IRRI (Gumma et al., 2012),

(iii) Mauza, Union and Upazila boundary from GIS unit,

Bangladesh Agriculture Research Council (BARC)

(iv) Information on water sources for selected districts from, Bangladesh Bureau of Statistics (BBS).

Soil salinity map prepared by SRDI (Fig.2) has been used in this study. The salinity map has been scanned, geo-referenced (Projection: Geographic lat/long; WGS84) and digitized (classes -non-saline to very slightly saline, very slightly saline to slightly saline, slightly saline to moderate saline, moderate saline to strong saline and strong saline to very strong saline) in Arc GIS platform. Other ancillary maps - physiography, rice growing area and forest were also brought to GIS format.

Out of the five salinity classes, class 1,2 and 3 (very slight to moderate salinity classes) have been separated and intersected with the mauza (lowest administrative unit), union, upazila and district boundary. The mauza where rice is not grown in any season has been deleted. Finally, the list of suitable mauzas, union, upazila and district along with maps have been prepared. The flow chart showing the steps used in the methodology of site suitability analysis have been given in Fig.3.

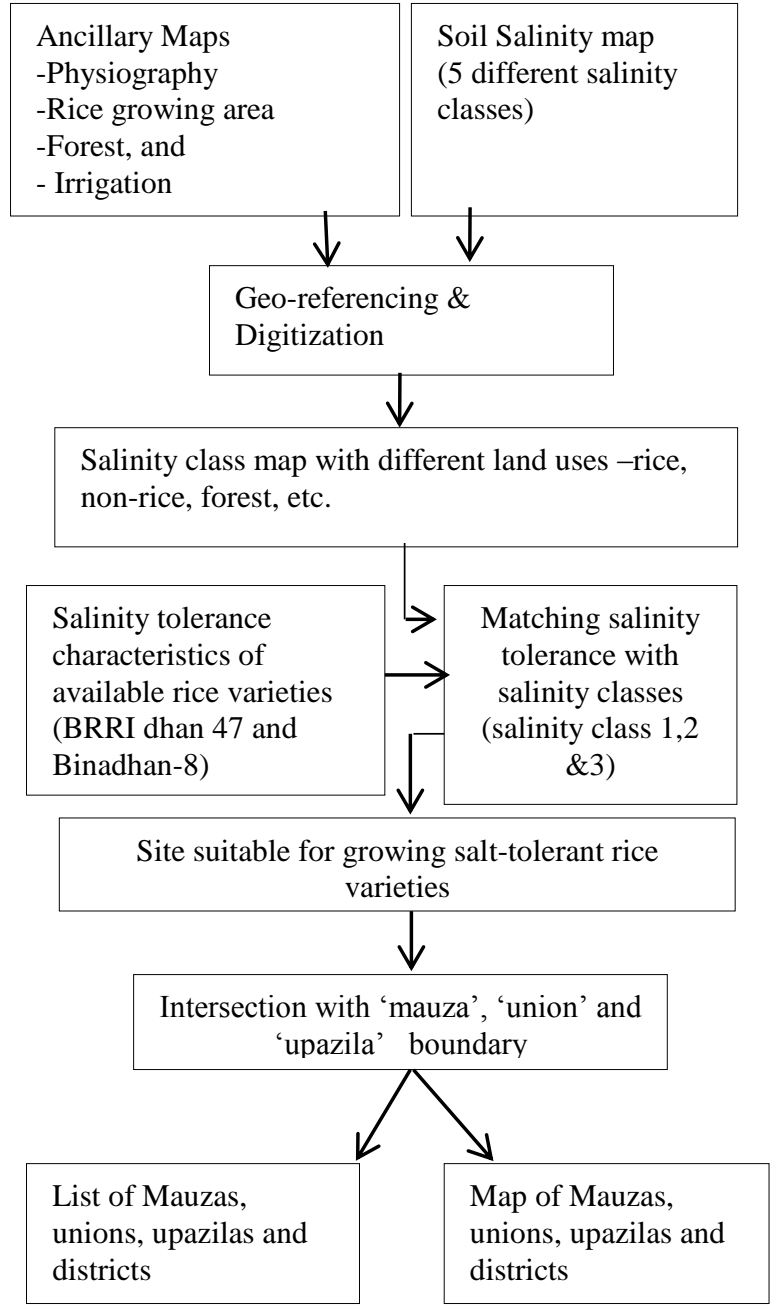

Fig. 3 Flow chart showing the methodology of site suitability analysis for salt-tolerant rice varieties

\section{Result and discussion}

The site suitability map for dissemination of salt-tolerant rice varieties in the study districts and upazils has been presented in Fig. 4. The map shows the following classes

(i) Suitable sites for salt-tolerant rice varieties (very slight salinity to moderate salinity area),

(ii) Not suitable for salt tolerant rice varieties (severe to very severe salinity area), and

(iii) Non-saline area, suitable for other high yielding rice varieties.

Upazila-wise maps showing suitability of mauza have been prepared for all the districts. In all, 65 upazilas are affected with salinity in the 12 districts. A sample map of Batighata upazila in Khulna district showing suitable and not suitable mauzas has been presented as Fig. 5. A total of 4070 mauzas have been identified in the 12 study districts where salt-tolerant rice varieties can be successfully grown. A detailed mauza list was also prepared for each upazila, which is not being presented here due to brevity. The number of mauzas selected in the 12 districts for targeted dissemination is given in Table 4. 


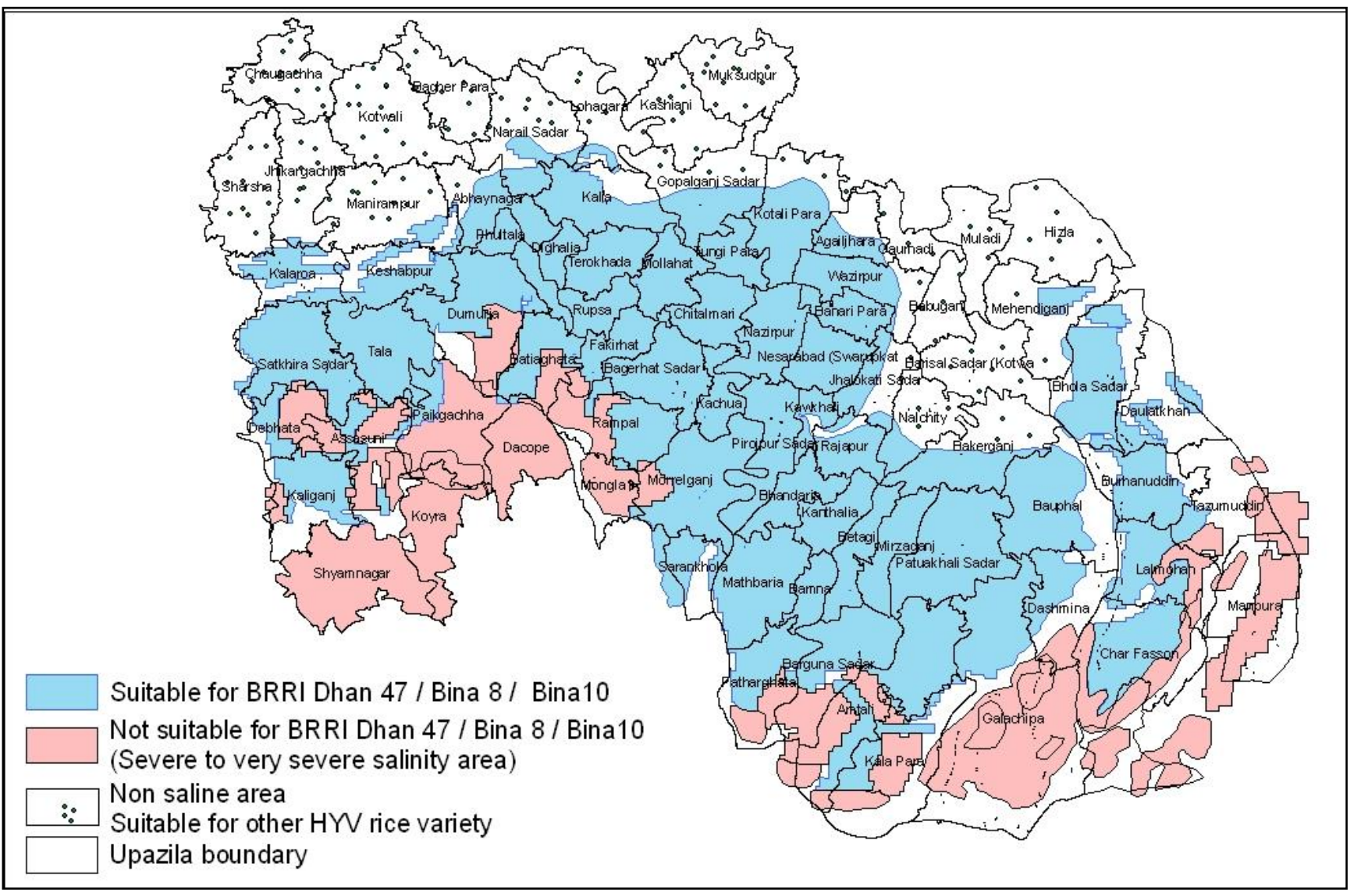

Fig.4 Site suitability of upazilas in southern Bangladesh for growing BRRI Dhan-47, Binadhan-8 and -10

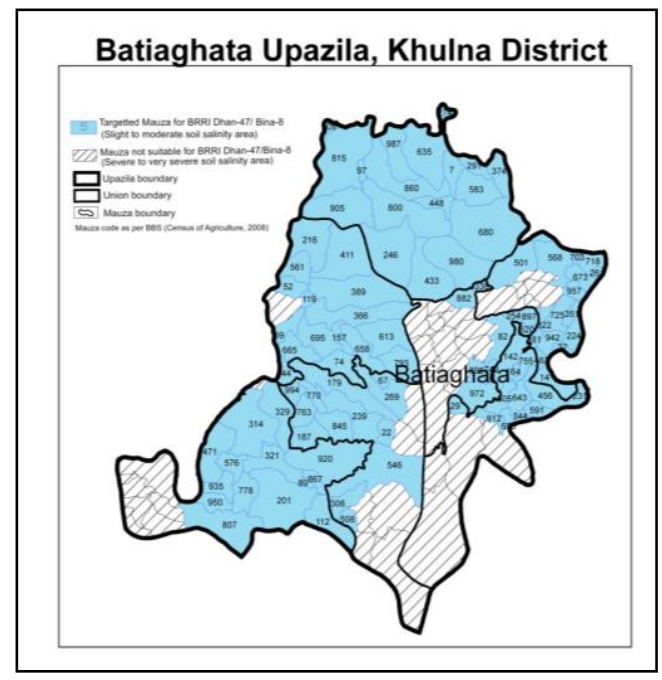

Fig.5 Map showing the suitable and non- suitable mauzas for the dissemination of salt-tolerant rice varieties in Batighata Upazila of Khulna district, Bangladesh

\begin{tabular}{|l|l|c|}
\hline \multicolumn{3}{|l|}{$\begin{array}{l}\text { Table 4. Number of mauzas suitable for } \\
\text { dissemination of salt-tolerant rice varieties }\end{array}$} \\
\hline & District & No. of suitable mauzas \\
\hline 1 & Bagerhat & 623 \\
\hline 2 & Barguna & 215 \\
\hline 3 & Barisal & 292 \\
\hline 4 & Bhola & 215 \\
\hline 5 & Gopalganj & 196 \\
\hline 6 & Jessore & 276 \\
\hline 7 & Jhalokati & 310 \\
\hline 8 & Khulna & 395 \\
\hline 9 & Narail & 132 \\
\hline 10 & Patuakhali & 428 \\
\hline 11 & Pirojpur & 395 \\
\hline 12 & Satkhira & 593 \\
\hline & & 4070 \\
\hline
\end{tabular}




\section{CONCLUSION}

The study has shown that remote sensing and GIS can be successfully used in carrying out site suitability analysis for targeted dissemination of salt-tolerant rice varieties BRRI dhan47, Bina dhan-8 and -10 in salinity affected districts of southern Bangladesh. A total of 4070 mauzas in 65 upazilas of 12 salinity-affected districts have been found suitable for dissemination of these varieties. About 0.6 million ha out of total 0.87 million ha salinity affected area in the study districts have been found suitable for growing the salinity-tolerant rice varieties in the boro season. The maps and other generated information have helped the Dept. of Agriculture Extension (DAE) of Bangladesh in large scale dissemination of seeds of the salinity-tolerant rice varieties in different districts during 2012 and 2013.

\section{ACKNOWLEDGEMENTS}

The authors thank SRDI and BARC for providing soil map and administrative boundaries, respectively. Funding support provided by USAID for this research is also gratefully acknowledged.

\section{REFERENCES}

Gumma, M.K., Nelson, A., Maunahan, A., Thenkabail, P.S. and Islam, S., 2012. Rice cropping patterns in Bangladesh. Rice Today, 11(1):24-25.

Haque, S.A., 2006. Salinity problems and crop production in coastal regions of Bangladesh, Pak. J. Bot., 38(5), pp.13591365.

Khandker, S., Begum, K., Bhuiyan, M.H., Hassan, N., Sarker, S.C., and Asaduzzaman, Md., 2014. Adoption of Salt tolerant variety in the Coastal areas of Bangladesh, App. Sci. Report. 4 (1), pp.3-20. PSCI Publications, E-ISSN: 2310-9440 / P-ISSN: 2311-0139

Rahman, M.M. and M. Ahsan., 2001. Salinity constraints and agricultural productivity in coastal saline area of Bangladesh, Soil Resources in Bangladesh: Assessment and Utilization.

SRDI, 2010. Coastal Saline Soils of Bangladesh. Soil Resources Development Institute. Ministry of Agriculture, Dhaka, Bangladesh. pp.96.

Singh, A.N., Sinha, D.D., Bari, M.A., Ismail, A. and Singh, U.S. 2012. Site Suitability Analysis for Dissemination of Salttolerant Rice Varieties in Southern Bangladesh. International Rice Research Institute Bangladesh Office, Dhaka. pp.161.

Sarwar, 2005. Impacts of Sea Level Rise on the Coastal Zone of Bangladesh, M.Sc. Thesis, by Md. Golam Mahabub Sarwar, Lund University, Sweden 